\title{
Audiobooks: Reading Practices and Educational Technologies
}

\author{
Natalia Mikidenko ${ }^{1,2^{*}}$, and Svetlana Storozheva ${ }^{2}$ \\ ${ }^{1}$ Novosibirsk state technical university (NSTU), Novosibirsk, Russia \\ ${ }^{2}$ Siberian State University of Telecommunications and Information Science, Novosibirsk, Russia
}

\begin{abstract}
Digital technologies have made it possible to create and replicate educational content in various forms: text, video, and audio. The post-PC generation actively uses audio content. There is a tendency to demand audiobooks as a format of educational resources. The purpose of the article is to identify and describe educational technologies and reading practices related to audiobooks. The novelty of the research is the analysis of student practices of audio reading. Methods: The first stage includes a desk study of audio reading as an educational technology, its capabilities and limitations, the representation of audiobooks in universities' electronic libraries and the use of audiobooks in the educational process, educational technologies and practices of working with audiobooks. The second stage includes an empirical study of students 'practices of accessing and using electronic libraries in the process of educational (1), leisure (2) activities, readers' preferences for the reading format (traditional, audio reading) (3). Research results: With the development of digital technologies, electronic libraries have become a popular educational resource. The e-libraries extend the representation of the audio books. The possibilities and limitations of audio reading remain debatable. Audio reading as a resourcesaving technology (carefulness to vision, time optimization) has a number of advantages and at the same time requires the development of listening skills and critical perception of audio text.
\end{abstract}

\section{Introduction}

Digital technologies that are actively penetrating the educational process have raised a number of questions in the search for new educational technologies. How should the educational environment change under the influence of digital technologies? What digitalbased educational technologies allow you to solve the problem of forming a professionally competent specialist? What educational technologies activate the student's creative potential and maximize their capabilities? There was a discussion and search for solutions.

A model of "smart education" based on the following principles is proposed: 1) free access to knowledge; 2) individual approach to learning for everyone; 3) mutual learning of a group or community [1].

\footnotetext{
* Corresponding author: $\underline{\text { nl_nsk@mail.ru }}$
} 
A whole field, called smart pedagogy for smart learning, is being developed,which aims to answer questions about the use of artificial intelligence in educational systems, the impact of digital technologies on the perception and cognition of reality, social interactions, and educational practices. Digital objects are transformed from tools of educational technologies or educational environments into learning subjects whose mission is to digitalize achievements to help the student and their mentor. Digital technologies allow you to build individual educational trajectories.

One of the elements of the educational smart environment is a new format of library systems that integrate educational content of various types: electronic printed books, multimedia sources (audiobooks, audio and video materials, electronic periodicals, etc.). However, despite the resources that are spent on the development of electronic libraries and the accumulation of experience in creating electronic libraries with different types of data (e-books, audiobooks, music collections, catalogues of museum collections, video materials, etc.), their use in educational practice remains insufficiently active.

The growing popularity of audiobooks and the transformation of modern reading practices, one of the most popular variants of which is audio reading, determine the problem of their inclusion in educational technologies and evaluating the use of audio content in educational practices. This led to the choice of the focus of this study, which is aimed at describing the practices of using different types of electronic library resources and identifying user preferences for the reading format (traditional, audio reading).

\section{Background theory}

\subsection{Resources for "smart education"}

There is an opinion that smart learning can be implemented in various ways, including nonformal learning opportunities. However, formal education in schools and universities is still a trend and it is their mission to generate and promote new educational technologies. Improving access to the network, enriching training terminals, creating a training support system, and improving information security are the most important steps to create a smart environment [2].

The education system is facing the pressure of Industry 4.0, which requires new competencies, the formation of which is no longer possible with the help of reproductive, monologue-based teaching methods that met the needs of the previous stage of development [3].

Dron J., examining ways to create a "smart" learning environment, implies creating an intelligent environment. The intelligence of the environment arises as a result of the interaction of structural and dynamic elements, the most significant of which (especially in online education) are creative, motivated subjects [4].

\subsection{Audio reading: reading practice and educational technology}

The demand for audiobooks increases [5] along with the consolidation of audio reading practices [6]. Audio reading is an alternative to paper and screen reading. Among the research on audio reading and audiobooks, a number of areas can be noted. This is a study of the history of audio culture in the twentieth century [7], the phenomenon of audio reading and its types [8]. Attempts to classify audio reading raise the question of the anthropology of audio consumption [9]. A separate direction is formed by works related to the study of audio formats [10]. The article discusses the use of audiobooks in the process 
of teaching native [11] and foreign languages [12]. The attention of researchers is paid to the reader's practice of reading different book formats (paper, screen, audio) [13].

Audiobooks have special features in comparison with a printed book: they help save time, make reading more comfortable for the audience, allow them to perceive familiar stories in a new way and even take care of their health, and at the same time require the skill to maintain attention for a long time [14]. Evaluating listening to an audiobook in comparison with reading, experts note that "this is a passive activity" in comparison with traditional reading, which requires active behaviors, including, for example, decryption and interpretation [15]. The issue of concentration of attention in the perception of an audiobook remains debatable, and opposite opinions are expressed. Thus, M. Rubery notes that "audiobooks do not require the same level of concentration as printed books" [15, p. 14], on the other hand, noting the formation of methods of "attentive listening". A comparative analysis of book perception practices is presented in the study by B. A. Rogowsky, where it is noted that no significant differences were found depending on whether a part of a popular science book was presented in an audiobook, electronic text, or in double mode, and a comparable understanding and memorization of the text is recorded regardless of the way it is presented [16]. S. Barinova notes that an audiobook requires the ability to maintain attention for a long time [14].

The growing popularity of audiobooks, according to experts, may be one of the main drivers of the growth of the e-book market [17], which, according to the forecasts of the Russian company EKSMO-AST, may show a sales growth of about $40 \%$ (in comparison, sales of printed books are projected to increase by only 5\%). Publishers are optimistic about the development of new book formats, but buyers still prefer paper products. In 2018 printed books accounted for $92.1 \%$, electronic books for $6.7 \%$, and audiobooks for only $1.2 \%$. But by 2022 demand for e-books is expected to increase by almost $15 \%$, and for audiobooks by $3.2 \%$ [18].

E. Lee (2020), assessing the current state of the main audiobook markets, pays attention to the use of audiobooks for educational purposes, their distribution and institutionalization for educational purposes [19].

K. Dali and L. Brochu, based on the analysis of the growing popularity of audiobooks as an accessible media and the choice for readers with and without disabilities, justify the equal status of audiobooks with printed books, wider recognition of audiobooks, and integration of audiobooks into the library collections of public, academic, and special libraries [21].

The review of the sources shows that the issues of theoretical understanding of the use of audiobooks as an educational technology require research attention, not only in the context of learning foreign languages, but also in a broader cultural context, and practical issues of creating and using audiobooks as educational content require attention.

\section{Results}

\subsection{Research method}

Methods and methodology. The first stage: a desk study of audio reading as an educational technology, its capabilities and limitations, the representation of audiobooks in universities' electronic libraries and the use of audiobooks in the educational process, educational technologies and practices of working with audiobooks.

The second stage: an empirical study of students' practices of accessing and using electronic libraries in the process of educational (1), leisure (2) activities, readers' preferences for the reading format (traditional, audio reading) (3). The study was conducted 
among students of higher educational institutions in Novosibirsk in March-May 2020. The sample size was 478 people.

The questionnaire included questions that reflect the opportunities that e-libraries provide to their users based on the resources placed in them: e-books, electronic periodicals, and multimedia (Figure 1).

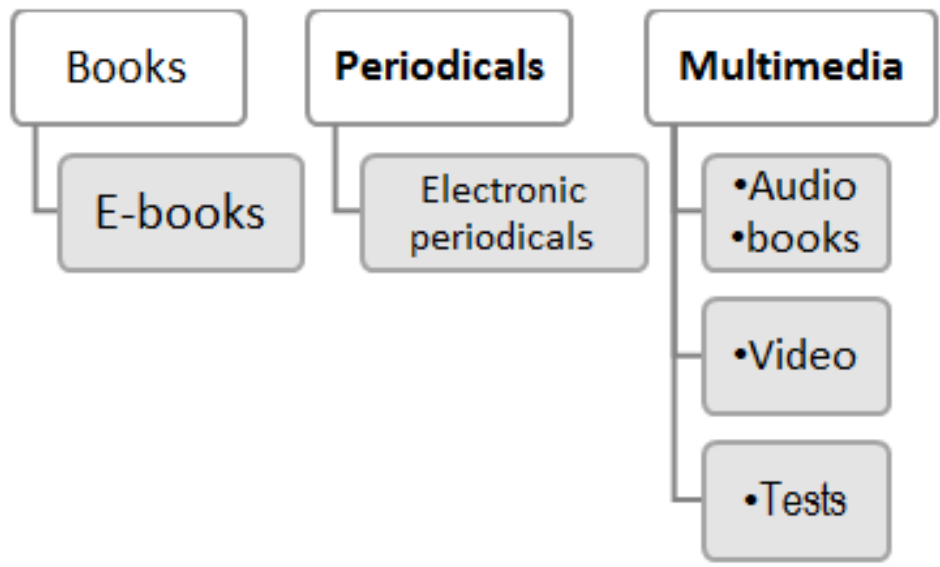

Fig. 1. Structure of electronic library resources.

Limitations of the study. Since audiobooks were considered as one of the possible resources offered by electronic libraries, the survey did not take into account more differentiated practices of using audiobooks, such as the frequency of listening, types and genres of texts listened to, commercial purchase of books or use of university subscriptions, user experience of listening to audiobooks, subjective assessments of the perception of audio information, etc.

\subsection{Audiobooks in students' reading practices}

Electronic libraries include various types of texts in their content: electronic printed books, audiobooks, and video materials. The frequency of access to different types of sources varies. According to the results of the study, the least popular approach was to the media content of electronic libraries. More than half of the students who took part in the study did not turn to media sources at all and do not consider electronic libraries as a resource that provides access to audio and video materials. This may be due to technical reasons, the quality of the material, or a subjective lack of motivation to use such content.

Table 1. Distribution of answers to the question "What features of electronic libraries have You used this academic year?" (closed question).

\begin{tabular}{|c|c|c|}
\hline \multirow{2}{*}{ Answers } & \multicolumn{2}{|c|}{ Answers } \\
\cline { 2 - 3 } & $\mathbf{N}$ & $\mathbf{\%}$ \\
\hline Very often & 41 & 8.7 \\
\hline Often & 77 & 16.3 \\
\hline Occasionally & 112 & 23.7 \\
\hline I don't use it at all & 243 & 51.4 \\
\hline Total, \% & 473 & 100 \\
\hline
\end{tabular}


Users were asked about their preferences in choosing how to get acquainted with the source: reading, listening, and video viewing. The distribution of responses to the question is shown in Table 2 .

Table 2. Distribution of answers to the question about choosing a way to read a book.

\begin{tabular}{|c|c|c|}
\hline \multirow{2}{*}{ Question } & $\mathbf{2}$ & Answers \\
\cline { 2 - 3 } & $\mathbf{N}$ & $\mathbf{\%}$ \\
\hline Read books & 252 & 53.3 \\
\hline Listen to books & 15 & 3.2 \\
\hline Both (depends on the information that is required) & 172 & 36.4 \\
\hline Other & 8 & 3.7 \\
\hline I can't answer & 26 & 5.5 \\
\hline Total, \% & 473 & 100 \\
\hline
\end{tabular}

About $40 \%$ of students turned to audiobooks during the school year. The choice of reading form depends on the type of information that the respondent needs. The received responses confirm the growing popularity of audio reading among students. At the same time, only $3 \%$ of students listen to books all the time. This may also be due to the special chronotope of listening to audiobooks, its pace, formed earlier practices of listening to audiobooks.

\section{Discussion and conclusion}

Digitalization and portability of information sources create new opportunities for technology development in the educational environment. The acceleration of digitalization of education determines the interest in the development of educational technologies related to the use of audio formats of educational information (audiobooks, audio podcasts) against the background of the projected growth of Generation $\mathrm{Z}$ interest in audiobooks and audio reading. At the same time, the innovative use of audio content for educational purposes requires understanding and solving issues related to the search for ways to create educational audio content, taking into account its communicative and cognitive capabilities and limitations, integrating audio content into the educational process, developing educational technologies for working with audio content, and solving issues of acoustic presentation of educational information.

V. Y. Bal' notes the emerging transition from scoring printed texts to creation of texts specifically for scoring; the shift of interest from novel to story, the relevance of sound design when editorial treatment of audiobooks and audiostream, composite building of several voices of the narrators, arranges a single idententical field $[9$, p. 56].

There is a need to develop content and stylistic strategies for preparing educational audio content, in accordance with the goals and objectives of the educational process, based on the possibilities and limitations of the audio channel of information perception. There is a need for specialists who design audio content, methods and technologies for its creation and application in the education of different types of subjects (school students, students, adults).

\section{References}

1. Y. Zhang, X. Li, L. Zhu, X. Dong, Q. Hao, What Is a Smart Classroom? a Literature Review, in: Yu S., Niemi H., Mason J. (eds) Shaping Future Schools with Digital Technology. Perspectives on Rethinking and Reforming Education. Springer, 
Singapore, 25-40, (2019) https://link.springer.com/chapter/10.1007/978-981-13-94393_2

2. N. Lorenzo, R. Gallon, Smart Pedagogy for Smart Learning, in: Daniela L. (eds)

Didactics of Smart Pedagogy. Springer, Cham, 41-69, (2019)

https://link.springer.com/chapter/10.1007/978-3-030-01551-0_3

3. J. Dron, Smart learning environments, and not so smart learning environments: a systems view, Smart Learn. Environ. 5, 25, (2018). https://doi.org/10.1186/s40561018-0075-9. https://link.springer.com/article/10.1186/s40561-018-0075-9\#Abs1

4. D. Liu, R. Huang, M. Wosinski, Smart Learning in Digital Campus, in: Smart Learning in Smart Cities. Lecture Notes in Educational Technology. Springer, Singapore, (2017) https://link.springer.com/chapter/10.1007/978-981-10-4343-7_4

5. Audiobooks: cross-media approach and working with the audience, University book, 9, 16-21, (2019). Audioknigi: krossmediynyi podhod i rabota s auditoriey (in Rus) eLIBRARY ID: 41266061

6. V. Yu. Bal', «Audio reading» as a modern modification of auditory reading, Tomsk State University Journal of Cultural Studies and Art History, 36, 5-12, (2019) / Audiochtenie kak sovremennaya modifikatschiya sluhovogo chteniya (in Rus) DOI: $10.17223 / 22220836 / 36 / 1$

7. Yu. P. Melentyeva, Audio reading: historical origins and current situation, Scientific and Technical Libraries, 9,45-50, (2008) / Audiochtenie: isoricheskie istoki i sovremennaya situatschiya (in Rus) eLIBRARY ID: 12876010

8. M. Yu. Gudova, Reading as a cultural practice: justification of the research methodology, Herald of the Chelyabinsk State Academy of Culture and Arts, 3(39), 82-88, (2014) / Chtenie kak kul'turnaya praktika: obosnovanie metodologii issledovaniya (in Rus) eLIBRARY ID: 21990351

9. V. Yu. Bal', Audiobook, audio podcast, audio series - new formats of media space, Bibliosphere, 1, 56-63, (2020) / Audiokniga, audiopodkast,aydioserial-novie formati mediaprostranstva (in Rus) DOI: 10.20913/18153186202015663

10. S. Rühr, Tondokumente von der Walze zum Hörbuch: Geschichte-MedienspezifikRezeption: V\&R unipress, Götting: V\&R Unipress. 463 s. (2008)

11. I. A. Shakirov, Audiobooks as an effective method of studying the Bashkir literary language and its classical speech in urban settings, in Modern problems of studying Bashkir and native languages. Materials of the III All-Russian (with international participation) scientific and methodological conference 15 February 2018, Ufa, Russia, 490-492, (2018) / Audioknigi kak effektivnyi metod izucheniya bashkirskogo literaturnogo yazika i ego klassicheskoy rechi v gorodskih usloviyah Materials of the III all-Russian (with international participation) scientific and methodological conference (in Rus) eLIBRARY ID: 32454619

12. E. A. Isakovich, M. A. Zakharova, The use of audiobooks in the process of teaching English to students of the specialty "Acting", Izvestia: Herzen University Journal of Humanities \& Sciences, 193, 98-106, (2019) (in Rus) eLIBRARY ID: 41257932

13. N. A. Maslenkova «Download and enjoy»: reading practices and new forms of books, Economics and sociology, 28, 13-17, (2015) / Kachai i naslazhdaisya: chitatel'skie praktiki i nofie formi knigi (in Rus) eLIBRARY ID: 26482849

14. S. Barinova, Why do I need audiobooks? 04.02.2019./ zachem nuzhni audioknigi? Website: EKSMO Publishing group. URL: https://eksmo.ru/trends/trend-audioknigiID15480657/ 
15. M. Rubery, Introduction: Talking Books, in M. Rubery, (Ed.). Audiobooks, Literature, and Sound Studies. New York: Routledge, 11, (2011).

https://doi.org/10.4324/9780203818039.

16. B.A. Rogowsky, B.M. Calhoun, P. Tallal, Does Modality Matter? The Effects of Reading, Listening, and Dual Modality on Comprehension, SAGE Open, JulySeptember, 1-9, (2016) doi:10.1177/2158244016669550

17. The book market of Russia. State, trends and prospects of development. Industry report. Moscow: Federal Agency for press and mass communications, 56, (2019) / Knizhnii rinok Rossii. Sostoyanie, tendentschii i perspektivi razvitiya. http://www.unkniga.ru/images/docs/kn-rynok-2018-1.pdf

18. The market for electronic and audiobooks will grow by $7 \%$ per year. 07.03.2019./ Rinok elektronnih i audioknig budet rasti na $7 \%$ v god. Website: Retail.ru URL:https://www.retail.ru/news/rynok-elektronnykh-i-audioknig-budet-rasti-na-7-vgod

19. Eun. Lee, A Study on the Educational Utilization Method of Audiobook. Korea Digital Publishing Society, 14, 22-34, (2020). 10.30580/kdips.2020.14.1.22.

20. Dali, Keren, Leah. Brochu, The Right to Listen: A Not So Simple Matter of Audiobooks, LRTS, 64, 106-119, (2020). 10.5860/1rts.64n3.106-119. 